\title{
2021 Handbook of Florida Water Regulation: Toxic Substances Control Act and the Lautenberg Chemical Safety Act ${ }^{1}$
}

\author{
Michael T. Olexa, Tatiana Borisova, and Jana Caracciolo
}

\section{Preface}

This handbook is designed to provide an accurate, current, and authoritative summary of the principal federal and state (Florida) laws that directly or indirectly relate to agriculture. This handbook provides a basic overview of the many rights and responsibilities that farmers and farmland owners have under both federal and state laws as well as the appropriate contact information to obtain more detailed information. However, the reader should be aware that because the laws, administrative rulings, and court decisions on which this handbook is based are subject to constant revision, portions of this publication could become outdated at any time. Several details of cited laws are also left out due to space limitations. This handbook is provided as an educational text for those interested in water use and water resource issues in Florida.

This handbook is distributed with the understanding that the authors are not engaged in rendering legal or other professional advice, and the information contained herein should not be regarded as a substitute for professional advice. This handbook is not all inclusive in providing information to achieve compliance with the federal and state laws and regulations governing water protection. For these reasons, the use of these materials by any person constitutes an agreement to hold harmless the authors, the UF/IFAS Center for Agricultural and Natural Resource Law, and UF/IFAS Extension for any liability claims, damages, or expenses that may be incurred by any person as a result of reference to or reliance on the information contained in this handbook. Note: UF/IFAS is the acronym for University of Florida, Institute of Food and Agricultural Sciences.

\section{TSCA and LCSA Overview}

The Toxic Substances Control Act (TSCA) of 1976 is intended to reduce the risk posed to the environment by the manufacturing, use, or disposal of toxic substances. The Act governs the manufacturing, disposing, importing, distributing, using, and processing of all chemical substances manufactured or processed in the United States (including imports) for uses under TSCA. "Chemical substance" is defined as "any organic or inorganic substance of a particular molecular identity, including any combination of these substances occurring in whole or in part as a result of a chemical reaction or occurring in nature, and any element or uncombined radical" (USEPA Act of 1976). These chemical substances include organics, inorganics, polymers, chemical substances of unknown or variable composition, complex reaction products, and biological materials.

1. This document is FE591, one of a series of the Food and Resource Economics Department, UF/IFAS Extension. Original publication date October 1998. Revised June 2017. Visit the EDIS website at https://edis.ifas.ufl.edu for the currently supported version of this publication.

2. Michael T. Olexa, professor, Food and Resource Economics Department, and director, UF/IFAS Center for Agricultural and Natural Resource Law; Tatiana Borisova, associate professor, Food and Resource Economics Department; and Jana Caracciolo, student, Levin College of Law; UF/IFAS Extension, Gainesville, FL 32611.

The Institute of Food and Agricultural Sciences (IFAS) is an Equal Opportunity Institution authorized to provide research, educational information and other services

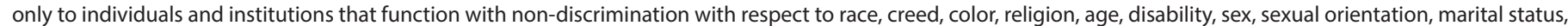

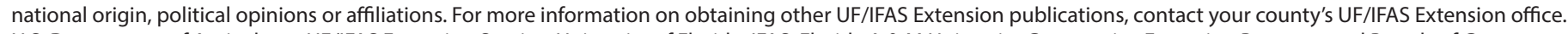
U.S. Department of Agriculture, UF/IFAS Extension Service, University of Florida, IFAS, Florida A \& M University Cooperative Extension Program, and Boards of County Commissioners Cooperating. Nick T. Place, dean for UF/IFAS Extension. 
The TSCA requires the United States Environmental Protection Agency (EPA) to compile, keep current, and publish a list of each chemical substance that is manufactured or processed, including imports, in the TSCA Inventory. The TSCA Inventory is comprised of "existing chemicals" that are currently found in the United States market. Note that some chemical substances may not be in the TSCA Inventory yet (so called "new chemicals").

The TSCA does not cover the following:

- Pesticides, and mixtures used as pesticides, that are covered by the Federal Insecticide, Fungicide, and Rodenticide Act (FIFRA)

- Tobacco or tobacco products

- Certain nuclear materials, source or byproduct materials covered by the Atomic Energy Act of 1954

- Chemicals that are covered by the Food, Drug, and Cosmetic Act (FDCA)

- Any article the sale of which is subject to tax under the Internal Revenue Code of 1986

To view a current version of the TSCA Inventory, please visit the EPA website (https://www.epa.gov/tsca-inventory/ how-access-tsca-inventory\#download).

The Frank R. Lautenberg Chemical Safety for the $21^{\text {st }}$ Century Act (LCSA) was signed on June 22, 2016; it amended the TSCA. The LCSA allows the EPA for the first time to evaluate the safety of existing chemicals in commerce, starting with those most likely to cause risks. The chemicals will be prioritized based on whether they are determined to be a high or low priority substance. Specifically, a high priority chemical substance is one that may present an unreasonable risk of injury to health or the environment due to potential hazard and route of exposure, including to the vulnerable populations like children, pregnant women, and the elderly. Once a chemical is determined to be a high priority, the EPA is provided a requirement and deadline on that chemical to determine its safety.

The LCSA sets deadlines for the EPA to complete risk evaluations of high priority existing chemicals. Within 180 days from enactment of the LCSA, the EPA was required to have risk evaluations for the first 10 high priority chemicals. Within 3.5 years, the EPA was to have at least 20 high priority chemicals under evaluation. Each evaluation must be completed within 3 years. Between June 22, 2016 and August 1, 2020, the EPA completed 2,854 evaluations.

\section{What are the restrictions on PCBs and mercury?}

The TSCA specifically dictates that the EPA must create restrictions for polychlorinated biphenyls (PCBs) as part of the mandate of the TSCA. In addition, the TSCA prohibits the transfer of any elemental mercury by a federal agency to any other federal, state, or local agency or to any private individual, except for transfers solely made for mercury storage or in relation to the transfer of coal. The LSCA requires the EPA to maintain an inventory of supply, use, and trade of mercury and mercury compounds. It also prohibits the export of certain mercury compounds.

\section{Per- and polyfluoroalkyl substances (PFASs)}

There are concerns regarding the presence of PFAS in the environment (e.g., groundwater and soil) and consumer products. PFAS are used in many products (e.g., cookware, carpet, furniture, and house appliances), and in the past, they were widely used to make products stain-, grease-, or water-resistant. Certain PFASs can accumulate in the human body, and exposure to PFASs can impact health. See more information at the Florida Department of Health's website (http://www.floridahealth.gov/environmentalhealth/hazardous-waste-sites/contaminant-facts/hw-pfas. html).

In 2020, US EPA received the authority under TSCA to review a range of products containing certain PFAS "before they could be manufactured, sold, or imported in the United States" (USEPA 2020). This implies that the products containing certain PFASs cannot be manufactured, imported, or sold in the United States without US EPA reviews and approval. More information on PFASs regulation can be found at the U.S. EPA website (https://www. epa.gov/assessing-and-managing-chemicals-under-tsca/ risk-management-and-polyfluoroalkyl-substances-pfas).

\section{What are the rules for new chemicals?}

Anyone introducing, importing, or manufacturing a new chemical must notify the EPA, as must anyone who obtains information that implies that a chemical represents a risk to health or the environment. Also, when an existing chemical is used for a significant new use, the EPA must be notified. The EPA will review the new use of the chemical substance to ensure that there is no risk of adverse effects. 
The TSCA requires that all new chemicals be inspected by the EPA. In all cases, the EPA must make an affirmative finding on the safety of a new chemical or a significant new use chemical before it may enter the market.

The TSCA has a whistleblower provision that protects employees from being fired or discriminated against by their employers because the employee has initiated or is about to initiate a TSCA hearing, has testified or is about to testify in a TSCA hearing, or has or is about to participate or assist in any manner in a TSCA hearing or in any other action to carry out the purposes of the TSCA.

\section{How does TSCA influence states?}

The existing state regulations remain intact; states can continue to act on any chemical that the EPA has not yet addressed. State action is preempted when the EPA finds that chemical is safe or final action is taken to address chemical risks. A state will be paused from taking action on a chemical under risk assessment; however, a state can apply for a waiver.

\section{Who enforces TSCA?}

The EPA is the sole authority for enforcement of the TSCA, although the TSCA specifically provides that the states are not prohibited from enacting their own legislation to regulate chemicals. The TSCA limits the state's power only to the extent that the state may not test new chemicals if the EPA is testing for the same purpose, and the state will be restricted from creating requirements that are different from those of the EPA concerning chemicals that have already been regulated by the EPA unless the state is given authority to do so by the Clean Air Act or other federal law or it restricts the use of that chemical in that particular state.

\section{How is TSCA enforced?}

The EPA may enact a wide range of restrictions on suspect chemicals, including

- Labeling/warning requirements

- Limits on concentrations of manufactured quantities

- Production/quality controls

- Recordkeeping

- Disposal criteria

The TSCA also gives the EPA power to enforce its provisions by injunctions (i.e., bans), restraint orders (i.e., an order to refrain from certain activities), forced inspections, and seizure of a product, as well as other means. The courts also have the power to restrain or force action on the part of producers to enforce the TSCA. These powers are broader with respect to chemicals that are identified as posing an imminent and unreasonable risk of serious or widespread harm. Also, the EPA may require the cleanup of areas where violations resulted in environmental damage.

\section{What are the penalties under TSCA?}

The EPA has authority to impose civil administrative fines of up to $\$ 37,500$ for each separate violation of the TSCA. Each day that a violation continues represents a separate violation. Before imposing a civil penalty, EPA must provide the violator with notice of the intended fine and the opportunity for a hearing. Also, willful or knowing violators may be subject to criminal penalties of up to $\$ 50,000$ per day per violation and/or up to one year of imprisonment.

\section{What are the exemptions under TSCA?}

National Defense Waiver: The EPA Administrator will waive compliance with any provision of the TSCA on the request and determination by the President of the United States that the requested waiver is necessary in the interest of national defense.

\section{Sources}

15 United States Code, Sections 2601 to 2671

More information about TSCA, see the EPA websites at https://www.epa.gov/laws-regulations/summarytoxic-substances-control-act, and https://www.epa.gov/ tsca-inventory/about-tsca-chemical-substance-inventory

\section{Acknowledgments}

The authors are indebted to the personnel of both state and federal agencies who provided their time and advice in the preparation of this handbook. We acknowledge Carol Fountain and Susan Gildersleeve at the University of Florida for their assistance in editing this handbook. We also acknowledge funding received for updating this publication from the James S. and Dorothy F. Wershow UF/ IFAS Center for Agricultural and Natural Resource Law Endowment. 